\title{
Boric Acid
}

National Cancer Institute

\section{Source}

National Cancer Institute. Boric Acid. NCI Thesaurus. Code C47416.

A weakly acidic hydrate of boric oxide with mild antiseptic, antifung al, and antiviral properties. The exact mechanism of action of boric acid is unknown; generally cytotoxic to all cells. It is used in the treatment of yeast infections and cold sores. 